\title{
Culture-Religion-Ethnicity (Alliance of Identities in the Environment of Foreign Slovak Communities)
}

\author{
Ladislav Lenovský *(D) and Katarína Slobodová Nováková *
}

Department of Ethnology and World Studies, Faculty of Arts, University of Ss. Cyril and Methodius in Trnava, 91701 Trnava, Slovakia

* Correspondence: ladislav.lenovsky@ucm.sk (L.L.); katarina.slobodova.novakova@ucm.sk (K.S.N.)

Citation: Lenovský, Ladislav, and Katarína Slobodová Nováková. 2021. Culture-Religion-Ethnicity (Alliance of Identities in the Environment of Foreign Slovak Communities). Religions 12: 883. https://doi.org/10.3390/rel12100883

Academic Editors: Michal Valčo, Jove Jim S. Aguas and Kamil Kardis

Received: 3 September 2021

Accepted: 10 October 2021

Published: 15 October 2021

Publisher's Note: MDPI stays neutral with regard to jurisdictional claims in published maps and institutional affiliations.

Copyright: (c) 2021 by the authors. Licensee MDPI, Basel, Switzerland. This article is an open access article distributed under the terms and conditions of the Creative Commons Attribution (CC BY) license (https:// creativecommons.org/licenses/by/ $4.0 /)$.

\begin{abstract}
Is religion and faith in today's economically and culturally globalized modern society just a conservative experience, tradition, and sentiment, or an anthropological universal, the primary essence of every individual and collective identity and a practical tool for realizing spiritual, cultural, and social needs? The community's culture, religion, and ethnicity are most significant in contrast (or on the border) with others. The existence of minorities is determined by their being defined against the majority and characterized by differences. Contemporary Slovak communities living abroad, such as ethnic, cultural, and religious minorities, are a compelling object of research into the relationship between culture, religion, and ethnicity. Our paper examines the role this relationship plays in their identification, cultural, and revitalization processes.
\end{abstract}

Keywords: religious roots of culture; religiosity; tradition; minority; identity; foreign Slovaks

\section{Introduction}

Today's world is economically and culturally increasingly globalized. It is technologically and communicatively connected in real-time with (thus far) unlimited and unbridled flows of ideas, knowledge, and information. It confronts the human community plated with new/different challenges, life strategies, value systems, and ideas/ideologies. The essence of what is generally considered obsolete, outdated, sometimes even detrimental is often attributed to the traditional, conservative. Today's society, which characterizes itself as modern, is mainly manifested as de-ethnization, demystification, delocalization, and deconfessionalization of its culture (as a way of life and thinking). It would seem that religion - like ethnicity, nation, one's own roots, and traditions-plays a decreasing role in a young individual's life, the prototype of the modern "citizen of the world." Are religion and faith in the culture of modern civilization only sentimental cultural relics without original features and values? ${ }^{1}$

Or is the question of human religion and belief an anthropological universal, one of the basic essences of man's complex identity ${ }^{2}$, regardless of time and space? If so, then all current discourse is more concerned about transforming forms, content, and visibility of religion and belief instead of its bankruptcy or retreat. The contemporary research of human societies no longer emphasized a strict separation of magic, religion, and science (or thusly aligned structures as cognitive systems representing the developmental stages of human culture) $)^{3}$.

The culture, religiosity, and ethnicity of a given human community are best revealed on its borders, in contrast to the surrounding communities. For this reason, such research tends to be more effective in the environment of minorities. They are, in fact, in confrontation (on the border) with the majority and other minorities in their "everyday" experience. Their existence is determined by a constant process of delineation of their boundary markers, which distinguishes them from the surrounding environment. Members of minorities are aware of their otherness and inner identity, cherishing and cultivating it more intensively 
and intentionally than the members of majorities. A member of the majority does not have to do anything to be one. A member of a minority (if he or she wants to be) must resist (sometimes natural) assimilation pressures/motivations. If he does not want to be one, he often finds himself in a difficult, even unsolvable situation ${ }^{4}$. Therefore, the same cultural, religious, or ethnic "issue" may assume a completely different position in the axiological system of a minority compared to the majority (Eriksen 2002).

The emergence and history of Slovaks as a Central European nation are a good example of ethnic, cultural, and religious processes because Slovakia historically lies at the intersection of migration, colonization, lowland and mountain culture, in an ethnically diverse situation of the overlapping Western (Roman) and Eastern (Byzantine) rites, which concerns not only religion but also culture and philosophy ${ }^{5}$. At the end of the Middle Ages, the territory of Slovakia found itself on the border of Hungary (or what remained of it during the Ottoman occupation) and the Ottoman Empire. Then it became part of the European political formations of the 20th century, and only recently has it enjoyed the abolishment of borders (?) and between the Eastern and Western Blocks (i.e., socialism and capitalism). Today, Slovakia finds itself at the border of the EU and the Schengen area, which it is part of. The territory of Slovakia, however, is not only a border area but also a mediator. This has been reflected in the way of life and thinking (culture) of its inhabitants. Although the population of Slovakia consists mainly of European nations, has a Christian foundation, and is undoubtedly part of European culture (in its anthropological and axiological understanding), it is not, and has never been, ethnically religiously or culturally homogeneous (Botík 2007). This becomes even more apparent in the communities that, as a result of the collapse of Hungary and the emergence of new states in the first half of the 20th century, so to speak, "overnight" found themselves outside the mother nation and its "own" territory. They suddenly became citizens of a new state and became surrounded by ethnic and religious "others" (e.g., Slovaks and Germans in Hungary, Romania, Serbia, Croatia; Romanians in Hungary and Serbia and Hungarians in Slovakia, Serbia, Romania, and Croatia). They became minorities (politically national minorities) (Šatava 1994; Kokaisl et al. 2014). What others took for granted, they learned to appreciate with utmost awareness. Ethnogenesis and historiography of Slovak minorities living abroad reveal that we can see, map, and historically understand these minorities by examining their religious, cultural, and ethnic identities ${ }^{6}$. It is as if these identities existed in one common alliance. The core concern of our study is how these "alliances of identities," if they really still exist, manifest themselves in the researched environment today.

\section{Materials and Methods}

The study is a partial result of long-term research of the identity and culture of Slovak communities abroad, emphasizing the contexts of culture, religion, and ethnicity. The information was obtained from field research between 2005-2020 in selected Slovak communities/localities in Hungary, Serbia, Romania, Croatia, Argentina, and Canada.

The criteria for selecting research sites were:

1. Absence of previous attention of researchers and a minimum of existing materials on the issue in the locality to supplement the existing knowledge.

2. On the contrary, the historical representativeness of the site and the amount of existing work to verify and revise existing knowledge in the context of changes and to confront general knowledge about the site and historical stereotypes with the current state and real perspectives.

3. Appropriate conditions for the implementation of field research (contacts, liaison officers, expected material in the locality, accessibility of the locality, financial, personnel and material support, access of community members).

4. The ambition to gradually capture the entire socio-cultural space in which the Slovak communities are located. 
5. Type of culture based on geographical conditions (mountain and lowland), livelihoods (agriculture and livestock, lumbering and forestry-crafts, mining and industry, services, administration), social organization (rural-urban or suburban).

6. The number of inhabitants and enclave character of the researched community (ethnoterritoriality), or the existing social network, where ethnicity is an organizational principle.

The criteria for selecting respondents were:

1. Slovak nationality or origin,

2. active membership in the ecclesiastical, cultural, educational or other Slovak community,

3. knowledge of Slovak language (except in Argentina),

4. willingness to cooperate,

5. possession of relevant information,

6. vitality and good memory (among seniors),

7. in some cases, only the identity and sharing of ethnicity and culture.

In some cases, the research was conducted through isolated one-week probes, in other instances during repeated two-week stays. Research stays in the Hungarian locations were carried out in the framework of research of ethnography (later interdisciplinary) camps organized by the Research Institute of Slovaks in Hungary (in Békešská Čaba). Part of the research in Serbia was carried out in cooperation with the Institute of Culture of Vojvodina Slovaks (in Novi Sad); the research in Romania was carried out in cooperation with the Democratic Union of Slovaks and Czechs in Romania (in Nadlac); in Croatia with the Slovak Cultural Center in Našice (in Našice); in Argentina with the Slovak Cultural Association in Buenos Aires, Slovak associations in Berisso (in Berisso), the Circle Slovak descendants in Chaco (in Presidencia Roque Saenz Peňa), the Czechoslovak association Bratři všichni (All Brothers) (in Resistencia) and in Canada with the Canadian Slovak League, the University of Ottawa (in Ottawa), Sts. Cyril and Methodius Slovak Parish (in New Westminster). The respondents were members of Slovak communities of all generations with a good level of command and understanding of the Slovak language.

Field research in Hungary, Romania, Serbia and Croatia was carried out within the relevant projects of the Ministry of Education, Science, Research and Sport of the Slovak Republic (APVV, VEGA and KEGA). Field research in Argentina and Canada was carried out mainly during the preparation and implementation phases of the relevant APVV project.

The list of research locations is as follows (year of research, name of locality by minority (official name of locality), area, county, type of culture, sources of livelihood, total population of locality, official or possible number of minority members estimated, minority religion, respondents-male/female, year of birth):

In Hungary:

1. 2005-Jášt' (Jásd), Transdanubia, the area of Bakonsky forest, Veszprém county, village, lowland culture with elements of mountain, agriculture, logging, coal mining, suburban tourism, 760, 50, Roman Catholic, men 1911, 1920, 1927, 1934, 1937, women 1919, 1925, 1932, 1933, 1936.

2. 2007-Békešská Čaba (Békescsaba), Lowland, Békés county, the county town, lowland culture, agriculture and livestock, food industry, state administration, 62.000, 1.880/2.500-3.000, Lutheran, men 1927, 1995, women 1950, 1951, 1960.

3. 2009-Senváclav (Pilisszentlászló), Piliš mountainous area, Pest county, village, lowland culture with elements of mountain, agriculture, logging, crafts in the city, suburban tourism, 1.170, 150/650, Roman Catholic, men 1939, 1940, 1946, 1949, 1956, women 1941, 1947.

4. 2011—Š́ra (Sári), Pripeštianska area, Pešt' county, village, today part of the city Dabas (Dabas-Sári), lowland culture with elements of suburban, agriculture and livestock, flower growing, industrial work in the city (50 km from the capital Budapest), 17.000 (city of Dabas) of which 5.000 (Dabas-Sari), 1200, Roman Catholic, men 1942, 1948, 1951, 1952, women 1925, 1935, 1940, 1953. 
5. 2013-Veňarec (Vanyarc), Novohrad county, village, lowland culture with elements of mountain, agriculture and cattle breeding, forestry, wood production, crafts in the town, 1.260, 190/450, Lutheran, men 1930, 1948, 1954, women 1930, 1932, 1935, 1950, 1957.

6. 2017-Tardoš (Tardos), Central Transdanubia area, Komárom-Esztergom county, village, lowland culture with elements of mountain, agriculture and cattle breeding, coal and surface mining, stonemasonry, forestry, suburban tourism, 1.600, 350, Roman Catholic, men 1933, 1934, 1941, women 1931, 1935, 1949, 1952, 1971, 1976.

In Serbia (autonomous part of Vojvodina):

1. 2009-Pivnica (Pivnice), Báčka county, village, lowland culture, agriculture and cattle breeding, crafts, 3.300, 2.600, Lutheran, men 1923, 1936, 1936, 1936, 1939, 1941, 1942, 1949, 1959, 1968, 1973, 1975, 1976, 1978, women 1939, 1944, 1947, 1951, 1965, 1971, 1976.

2. 2010-Bol'ovce (Boljevci), Belgrade area, village, lowland culture on the banks of the Sava River, agriculture and livestock, crafts and services in the city, suburban tourism (20 km from the capital Belgrade), 4.000, 1.000, Lutheran, men 1927, 1932, 1935, 1936, 1936, 1937, 1939, 1951, 1952, 1957, 1957, 1958, 1963, 1965, 1985, women 1929, 1933, 1934, 1937, 1938, 1942, 1950, 1961, 1961, 1963, 1964, 1967, 1984, 1985.

3. 2012-Silbaš (Silbaš), Báčka county, village, lowland culture, agriculture and cattle breeding, 2.500, 800, Lutheran, men 1921, 1922, 1928, 1938, 1940, 1944, 1949, 1955, 1960, 1965, 1973, 1986, women 1925, 1928, 1931, 1932, 1935, 1940, 1940, 1948, 1952, 1955, 1955, 1978.

4. 2014-Vojlovica (Vojlovica), Banat county, village, today part of the city Pančevo, lowland culture, agriculture and livestock, chemical, aviation and oil industry, 83.000 (city of Pančevo) of which 5.000 (Vojlovica-Pančevo), 800, Lutheran, men 1934, 1936, 1942, 1943, 1944, 1945, 1946, 1950, 1950, 1951, 1955, 1956, 1974, 1978, 1979, 1984, women 1934, 1934, 1938, 1946, 1948, 1950, 1950, 1951, 1978.

In Romania:

1. 2005-Borumlak (Borumlaca), Transylvania area, Bihor county, village, logging, cattle breeding, forestry, mining and oil and gas extraction, 550, 150, Roman Catholics, men 1926, 1935, 1936, 1938, 1941, 1946, 1950, 1973, women 1931, 1947, 1948, 1955, 1974.

2. 2005-Varzal' (Vărzari), Transylvania area, Bihor county, village, logging, cattle breeding, forestry, mining and oil and gas extraction, 300, 240, Roman Catholics, men 1927, 1934, 1934, 1948, 1957, women 1931, 1931, 1934, 1939, 1961, 1970.

3. 2007-Butín (Butin), Romanian part of Banat region, Timis county, village, agriculture and livestock, 450, 380, Lutherans 80\%, Roman Catholics 20\%, men 1920, 1929, 1935, 1940, 1941, 1945, 1946, 1947, 1976, women 1925, 1928, 1936, 1941.

4. 2016-Nadlak (Nadlac), Lowland, Arad county, town, agriculture and livestock, food industry, 7.400, 3.200, Lutherans 90\%, Roman Catholics 10\%, men 1968, 1968, 1971, 1988, women 1967, 1969.

In Croatia:

2013-Sol'any (Soljani), Slavonia area, Vukovar-Srem county, village, agriculture and livestock, lumbering, 1.250, 70, Lutherans 50\%, Roman Catholics 50\%, men 1931, 1936, 1941, 1956, 1959, 1959, women 1932, 1932, 1933, 1935, 1942, 1947, 1952, 1955, 1956, 1956.

In Argentina:

1. 2017-Buenos Aires (Buenos Aires), Province of Buenos Aires, Buenos Aires metropolitan area, city, crafts, administration, services, education, 15.000.000 Buenos Aires metropolitan area, 3.000.000 Buenos Aires city, 30 (members of the Asociación Cultural Eslovaca in Buenos Aires), Roman Catholics, men 1940, 1942, 1968, 1995, women 1944, 1950, 1970.

2. 2017-Beriso (Berisso), Province of Buenos Aires, La Plata metropolitan area, city, trade, packaging and refrigeration industry, services, 90.000, 50 members of Colectividad Eslovaca Berisso, Roman Catholics, men 1945, 1966, 1995, women 1951, 1952, 1981. 
3. 2017-Saenz Peňa (Presidencia Roque Sáenz Peňa), Province of Chaco, city, agriculture and cattle breeding, crafts, 90.000, 80 members of Unión Checoeslovaca (including folklore ensemble Moravanka), Lutherans and Roman Catholics (ratio unknown yet), men 1935, 1940, 1995, 1998, women 1945, 1950, 1962, 1990, 1996, 1997.

4. 2017-Resistencia (Resistencia), Province of Chaco, city, agriculture and livestock, services, crafts, 300.000, 20 members of Circulo de descendientes Slovaks of Chaco (including Asociacion civil Checoslovaca Bratři Všichni), Lutherans and Roman Catholics (ratio unknown yet), men 1948, 1950, 1950, 1952, 1975, women 1931, 1949, 1950, 1955, 1990, 1992.

In Canada:

1. 2018-Venkúver (Vancouver), Province of British Columbia, city, services, crafts, industry, 600.000, 6.000, Roman Catholics, men 1945, 1948, 1975, 1978, women 1968, 1970, $1972,1975,1986$.

2. 2018-New Westminster, Province of British Columbia, Lover Mainland of Vancouver area, city, services, administration, crafts, 70.000, 120 registered members' families in Slovak Church of Sts. Cyril and Methodius in New Westminster, Roman Catholics, men 1962, 1980, women 1948, 1975, 1980.

3. 2019-Ottawa, Province of Ontario, city, services, administration, crafts, 810.000, 2.000, Roman Catholics, men 1943, 1974, 1981, woman 1951.

In addition to participatory and non-participatory observation and semi-standardized and standardized interviews, we also conducted archival research (university archives, parish archives, archives of private individuals) and heuristics in scientific, professional, and popular works. These are private archives of almost all respondents (family photographs, notes, diary entries) and archives of church congregations in the surveyed localities (registries of born, married, deceased) to obtain qualitative and quantitative information about the culture and identity of communities and their members.

\section{Results}

In addition to the vision of a rapid improvement of their socio-economic situation, it was in many cases precisely the political, ideological, and religious freedom that motivated the inhabitants of Slovakia temporarily or permanently to leave home and establish a new one. ${ }^{7}$

\subsection{Lowland Migration}

In the case of the colonized areas of Austria-Hungary, later the Kingdom of Hungary, it was mainly Protestants (mostly Slovaks) from all parts of the monarchy who were allowed during recatholization to freely pursue their religion in the then liberated and depopulated areas of central and southern Hungary, previously occupied by the Ottoman Empire. The owners of these territories (the Church, the army, and nobility) needed to revitalize them and therefore resettled the willing inhabitants through colonization programs, support incentives, tax breaks, etc. The descendants of these Slovak colonists are Slovaks (or inhabitants of Slovak origin) in Hungary, Serbia (in the autonomous part of Vojvodina), Romania (in the western and northwestern parts-Arad and Bihor-Salas counties), and Croatia (northeastern part-Slavonia). This is the period from the turn of the 17th century to the 19th century and the subsequent regional and national migrations that continued well into the 20th century. ${ }^{8}$

A rural "white bread culture" characterizes these Lowland Slovaks-an agrarian lowland culture based on the cultivation of thermophilic crops (wheat, corn, hops, vineyards, fruit) and the breeding of livestock (especially sheep, pigs, and poultry). In the mountain areas, they were also known for logging and mining. During the 20th century (especially in its second half), in connection with industrialization and urbanization, the character of culture in some localities expanded to include non-agricultural industrial professions and acquired the characteristics of urban or suburban environments. On their arrival, 
Slovak colonists established or rejuvenated extinct rural cities that have since also become ethnically homogenous. If German-speaking colonists mostly repopulated an area, Slovak colonists settled down in smaller, segregated communities, which later also became ethnically homogenous. Over the next 250-300 years, these communities became so numerous (hundreds, sometimes up to thousands of members) and internally vital that they were able to meet all their needs (livelihoods, reproduction, spiritual, social, and cultural resources) on their own or through contacts with other Slovak enclaves enjoyment). ${ }^{9}$ The reason behind the preservation of the ethnic identity was their ethnic/religious/local endogamy and everyday use of ethnic markers (especially the use of Slovak language at home, in the local society, schools, churches, and the implementation of cultural traditions). ${ }^{10}$

\subsection{Overseas Migration}

Slovak emigration from their home country (i.e., Hungary, Czechoslovakia, and the later Slovak State) was mainly represented by labor migration to Western Europe (notably Austria, Germany, France, Belgium, and more recently England) and transatlantic migration (enormous in the period from the 1880s to the First World War) to the USA, then to Canada and South America, especially Argentina ${ }^{11}$. Emigration to the United States and Canada, even though to a much lesser extent, continues today ${ }^{12}$.

The underlying conditions and assumptions of the Lowland Slovaks, compared to Slovak emigrants to Western Europe and overseas, were significantly different. Emigrants to the West worked primarily in the industry (mining, metallurgy, textile, food, and transport industries), while those with higher education found work in the services sector and administration. Far fewer of them worked in the logging industry (for example, on the west coast of Canada) and the agricultural sector (for example, cotton growers in the Argentine province of Chaco) (Botík 2002). Most of them, however, settled in an urban or suburban environment. Initially, the territorial principle of migrants' settlement manifested itself most clearly. As migrants came in several migratory waves that often had the same source and destination sites of migration, this resulted in the creation of common settlements (villages, neighborhoods, workers' and mining colonies). Therefore, local societies of ethnically or religiously homogeneous migrants emerged here as well. However, the current situation of the descendants of these Slovak migrants is different. Today they live scattered in numerous diasporas-in exogamous communities, without self-sufficiency in reproduction or livelihood that would be tied to their specific ethnic group. Similarly, the fulfillment of their spiritual, social, and cultural needs does not primarily happen in the context of their own ethnic group. Being "Slovak" is not an everyday issue but rather an exclusive feature. It takes place almost exclusively through specific opportunities, most of which are formalized and institutionalized in character (including worship services in the Slovak language). It is now more about social entities in terms of social networks, rather than traditional local fellowships (communities) in terms of secondary social groups with distinctive features of primary groups (Bauman 2001).

In what follows, we will pay attention to religion and the Church's role in these ethnic processes.

\subsection{Magyarization}

Magyarization, culminating at the turn of the 19th century in the Kingdom of Hungary and the first half of the 20th century in the Republic of Hungary, was perpetuated by all governmental, educational, and religious institutions to displace the language of minorities from the political, cultural, and social life in the country. Their main argument was that the promotion of the Hungarian language was not about ethnicity but about the matters of the state and the related educational and religious issues (which by their nature are non-ethnic) and, therefore, there was no reason to support the implementation of educational and religious measures in other than the state language. Such efforts revolved around the question of citizenship and patriotism, not ethnicity (Michela 2009; Filadelfi 2012; Deák 1992). During the second half of the 20th century, the Slovak language in Hungary completely dis- 
appeared from the people's religious life and the Church. This happened even though the number of Slovaks and residents who acknowledged their Slovak origin was still around 100.000 at that time. In the environment of Slovak communities in Hungary, only residues have been preserved in the form of folk religiosity of the oldest inhabitants, who can still pray, sing religious songs, and read legends in Slovak. In some cases, though this is rather exceptional, worship services are held in Slovak several times a year (mostly on festive occasions). This is despite the fact that Slovak Lutheran churches were among Hungary's largest and most numerous Lutheran churches. For example, the Lutheran congregation in Nyíregyháza had about 100.000 members in the 1920s and 1930s and accepted only Slovak priests as their leaders (Divičanová 2007). Following the Magyarization, the number of members of these churches decreased rapidly, which, of course, was related to the overall secularization of society and applied to all religions. However, doubts about whether secularization was truly the main force behind it are raised by a later example from Serbia (Lenovský 2017).

\subsection{Catholic Croatia Majority}

A similar trend of religion being an assimilation factor can be observed among Slovaks in Croatia, albeit for completely different reasons. Catholic religion prevails among the Croatian Slovaks as well as among the Croatian majority. In addition, the affinity and similarity of Croatian and Slovak languages never gave rise to such a sharp boundary, as was the case between the Hungarian and Slovak languages. Slovak as the language of the realization of religion here was rather a sign of the ability of the local community to build and maintain its own "Slovak" parish, including the administration of the church building and the congregation. For economic and administrative-governing reasons, a linguistic and later an ethnic fusion were easier and more natural for the local believers. That which had been characteristically "Slovak" has gradually disappeared from the religious life of Slovak Catholics in Croatia.

\subsection{Eastern Orthodox Majority}

In the Eastern Orthodox countries of Romania and Serbia, ethnic self-identification of the local Slovaks went hand in hand with their Lutheran faith (in the Bihorska region of Romania, it was Catholic faith) and was linked to a different socio-economic status. Slovaks occupied a leading position here in the imaginary cultural and social hierarchy until the middle of the 20th century, right after the Germans ${ }^{13}$. After World War II, Germans lost their privileged status and became marginalized, ostracized, and officially almost completely extinct as a minority. The Slovak Lutheran Church still functions as a separate enclave linked to Slovak minorities in Romania and Serbia. It seems that the Church is more aware that its successful existence is conditioned by the preservation and functionality of Slovak enclaves. The story mentioned above of Slovak Lutherans in Hungary serves as a memento, perhaps. These churches remained prosperous as long as their Slovak identity was upheld and cherished. The number of their members, along with their vitality, was significantly reduced by subsequent Magyarization. Such was the case of the Slovak community in Békešská Čaba, Hungary. This town was the largest settlement of Slovaks (Slovak-speaking population) globally at the turn of the 19th and 20th centuries. Even in the territory of Slovakia at that time, there was no urban settlement with a higher number of Slovak-speaking population (Kováčová 2014; Borgul'a and Ladislav 1979; Jančovic 2017; Paríková 2001).

The almost ethnically homogeneous Slovak community of Békešská Čaba that counted over 40.000 members around the year 1900 became a Hungarian city with 64.000 inhabitants, where a small, $5.9 \%$ minority (i.e., 1880 inhabitants), still claims to be Slovak ${ }^{14}$. Slovak Lutherans used to be so economically powerful in this city that they built the largest brick Lutheran church building in Central Europe (its capacity was 3600 seats). Today, only about $20.5 \%$ (about 13.000) Békešská Čaba inhabitants claim to be Lutheran. The current attendance of worship services in the "Great Temple" is counted in the 
tens, and only about 20 elderly women attend the Slovak language worship service (See: Lenovský $(2016,2017,2018))$. In the Slovak enclaves in Serbia, on the other hand, although the number of Slovaks there is also declining due to demographic developments and intergenerational assimilation by exogamy, the number of members of local churches is not declining so rapidly. The issue of Protestantism is here for members in general not only a matter of tradition and continuity, but also a declaration of Slovak nationality and the previously mentioned higher cultural, social, and economic status as a historical ethnostereotype. The emphasis here, of course, is to have enough members who can financially secure the operation of the Church, including paying for the priest's salary. It is a high priority to hire a Slovak-speaking priest. However, it is worth noticing that the current generation of Slovak Lutheran priests in Serbia and Romania consists almost exclusively of graduates of seminaries in the Slovak Republic.

\subsection{Religious Identity vs. Ethnic Identity}

To what extent is religious identity an organizing principle of creating Slovak communities and a factor in their diversity in the individual countries, regions, and locations?

\subsubsection{Slovaks in Canada}

For example, Slovaks in Canada are largely grouped according to their religion. Large Slovak communities in Toronto are created and exist not only based on their area of origin, i.e., Slovakia, Lowlands, or previous Czechoslovakia (this aspect is present here as well), but also based on whether they are Roman Catholics (from Slovakia, exceptionally also from Bihor, Romania), or Orthodox (from northeastern Slovakia), or Lutherans (mostly from the Lowlands). In addition to participation in cultural events and visits to cultural institutions and associations, the source of contacts among expatriates is mainly their attendance of religious services in a particular church, around which the relevant group of Slovaks associate. For example, in the city of New Westminster (near Vancouver) is St. Cyril and Methodius Slovak parish, which was built by Slovak Catholic believers from their own resources, including the purchase of land, the construction of a church, and an adjoining community hall. A community hall is a place where Slovak Catholics of all generations meet for lunch every Sunday after Mass. They prepare typical Slovak meals and spend Sunday afternoons together. There is also a Slovak children folklore ensemble that rehearses on the church premises during the week. Worship services are also attended by new immigrants from Slovakia, who have learned about the Slovak church services and feel the need to be spiritually rejuvenated and anchored in the social web of the Slovak community. Members commute to parish premises across long distances, sometimes dozens of kilometers. The more economically successful ones make a significant financial contribution. The community thus exists not only as a Catholic but also as a Slovak one. Many of them would otherwise probably never meet.

The parish has been without its own Slovak priest in recent years, and despite the requests, it has not been possible to get him due to the general lack of priests in Slovakia. The services were performed by an authorized priest of Indonesian origin, who spoke English poorly and did not speak Slovak at all. Even though it is a single Slovak parish on the west coast of Canada and thus can be considered unique, it might eventually fall under the administration of an English-speaking Church body (a Roman Catholic diocese, in this case). Finally, a Slovak priest was sent to the parish and has been working here since February 2021.

Our examination of these immigrant groups indicates the essential significance of practical engagement- the practical level is an important aspect of the relationship between culture, religion, and ethnicity. The community of believers is historically a tool for creating and maintaining contacts, socialization, a space for mutual help. Slovak believers in Canada do not hesitate to worship in any place/parish of their own religious denomination if it suits their logistical needs, or if they like a certain priest or other members of the Church, or because of prestige or simply because the Church is readily available. Of course, not all 
Slovaks here want/need to identify as Slovaks or participate in ethnic-based activities and form groups on an ethnic or religious basis.

\subsubsection{Slovaks in Argentina}

The city of Buenos Aires in Argentina and its numerous Slovak immigrant communities reflect the political and economic developments in Slovakia during the 20th century. This immigration wave (as the second wave of Slovak immigration to Argentina) comprised those who were forced to emigrate from the territory of Slovakia after they had been marginalized, ostracized, and persecuted in their domestic political and economic environment. In addition to the poorest segments of the society, these immigrants also represented the persecuted population, or members of the executive branch, the Slovak intelligentsia, and other figures of the social establishment that the new, totalitarian regime had suppressed. Except for Jewish migrants, the religious side was secondary in the process of this migration. Put simply, many of those who came to Argentina and the US as part of the second wave of Slovak immigration were those because of whom the first wave of immigrants had initially taken place. Accordingly, they have regrouped and still operate in a new environment. The current situation calls for more detailed research in light of the generational change that has taken place in recent decades.

An interesting example of Slovak immigration to Argentina is the structure of their communities in the province of Chaco (as part of the first wave of Slovak immigration to Argentina in the first half of the 20th century). It consists mainly of Slovak Lutherans from the lowlands, who opened a Slovak school in their new homeland in 1934 and built a Slovak Lutheran Church in 1935. In addition, Chaco was also settled by Catholics from the Moravian village of Velké Bílovice with a Czechoslovak identity. The need for research into the current situation is significant here due to generational changes in recent decades.

\subsection{Folk Religiosity, Lived Religion}

Besides their origin and language (which is not always actively used anymore), religious elements are considered as special and exceptionally valuable ethnic markers in the environment of Slovak immigrant communities. The nature of these elements is partially dependent on the locality of immigrant communities. For example, the Lutheran Church Hymnal "Tranoscius," composed by the famous Juraj Tranovský (or: Jiří Třanovský), served not merely as a hymnal and a prayer book, but also a family artifact handed down intergenerationally that enjoyed exceptional reverence. In addition, occasional worship gatherings in Slovak, individual and group prayers in Slovak ${ }^{15}$, dressing in a folk costume, or at least some parts of it (e.g., men wore embroidered "Slovak" shirts) to attend services during the most important church holidays, Slovak coat of arms, tricolor or the Slovak national flag as part of the interior decoration of the Church, the current Slovak Catholic or Lutheran calendar hanging on the wall in the interior of a household and the like.

Most members of the younger and middle generations point out that even though they declare their religious identity in censuses and are consciously aware of it, they no longer actively practice their religion, nor do they regularly attend religious services. A vast majority of them show up at Church during Easter and Christmas holidays. They often claim that they are not existentially interested in religion, the Church, or the faith. On the other hand, during detailed descriptions of their family's life cycle (at birth, adolescence, wedding, death, etc.), these respondents reveal that they retain and cherish the pre-Christian and Christian core of customs and rituals that their families observe. Despite certain innovations, the general perception of the kept customs and rituals is directed towards the same function: health, fertility, success, sufficiency, God's protection, and help for oneself and one's family (Lenovský 2018). In addition, their value system, worldviews, life strategies, and concepts of good and evil come from their religion. Their latent religiosity is thus clearly manifested.

Especially in less developed, isolated, and poor localities, the position and authority of the priest in the vertical social hierarchy is high. This is true not only within the given 
ecclesial community but throughout the local society. For example, the local Orthodox Romanians contributed to the repair of the Slovak Catholic parish (in one of the researched localities during the research) as volunteers because the Catholic pastor provided spiritual counseling to all who needed it and was a recognized authority by the whole community. Regardless of their religious affiliation, children and young people could come to watch cartoon films and movies with religious topics to the Catholic parsonage when DVD players were not yet widespread. Another example of such an ecumenical approach is a Slovak Lutheran pastor (his Church had 3500 members) in the village of Pivnica (3300 inhabitants, $80 \%$ of them Slovaks). He set up a youth club with a playroom, computers, and internet connection on the premises of the parish at a time when such infrastructure was not readily available. The members of the Christian youth were in charge of the equipment and managed its use. In addition, the village of Pivnica became the first one in all Vojvodina County to establish a social services center for local seniors, including daycare and meals. The center was built in a diaconal house, the purchase of which for the local Church was financed by an Australian Slovak originally from Pivnice. The local church congregation decided how the property was to be used. Congregational members also implemented the project. In front of the building, there is also an ethnographic exposition. Slovak church congregations further organize activities, such as summer camps for children and youth. Besides being ecumenical, these camps are also focused on getting to know Slovakia, Slovak children from other enclaves, and making new contacts. Regular Sunday school for children or meetings of confirmands are a Lutheran "Church" affair and a Slovak affair (Lenovský 2017). Priests (and congregations) in the context of the life of Slovak minorities in the world are not only a historical and historiographical phenomenon; they are also important moderators of the current existence of these minorities.

\section{Conclusions}

Our research can conclude that religion and religious culture have a much more prominent role than expected in the studied environment. Religious identity, along with ethnic and cultural identities, stimulate the immigrant minorities and promote intergenerational transmission of culture and the community's complex identity. Even though the existence of lowland and overseas Slovaks is based on different developmental lines, the role of religion, the Church, and the faith in their previous and current identification, culture- and revitalization processes can be equally important.

Whether we are talking here about an enclave or diaspora character of the various Slovak communities in the world, or whether they no longer exist or have been assimilated, is significantly affected by their religiosity, including the specific ways of organizing religious life and the local churches' attitude. Cases from the field show that although Christianity is non-ethnic, it can be an effective instrument of ethnic assimilation, or on the contrary, a significant factor in the development of a minority community. A practical lived form of religion can be a tool for building a community's cultural and social capital. Faith and religiosity in the environment of minorities can be an equally important organizing principle of creating groups, as are ethnicity and cultural traditions. Confessionalism in Slovak communities expresses itself manifestly (in the forms of church ceremonies and significant religious rituals) and latently, as an unconscious and, at the same time, the primary paradigm of perception and image formation about the world, society, and itself. The bearer of these values is the cultural tradition perceived as a value. Religious, ethnic, and cultural identity together forms a robust alliance, which constitutes a pillar of minority identity of Slovaks and citizens of Slovak origin. Its strength is directly proportional to the integration of these identities.

Author Contributions: Conceptualization, L.L. and K.S.N.; methodology, L.L.; validation, L.L. and K.S.N.; formal analysis, L.L.; investigation, L.L. and K.S.N.; resources, L.L. and K.S.N.; data curation, L.L.; writing — original draft preparation, L.L. and K.S.N.; writing — review and editing, L.L.; supervision, L.L.; project administration, L.L.; funding acquisition, L.L. All authors have read and agreed to the published version of the manuscript. 
Funding: This research was funded by Slovak Research and Development Agency: 20-0263.

Institutional Review Board Statement: Not applicable.

Informed Consent Statement: Not applicable.

Data Availability Statement: Not applicable.

Conflicts of Interest: The authors declares no conflict of interest.

\section{Notes}

1 For a closer look at the issue of the relationship of tradition and identity in the studied area, see: Babiak (2019, pp. 7-8). He asks: 1. "To what extent is the problem of national culture legitimate and to what extent anachronistic today?"; 2 . "Will the questions of the newly established identities of the contemporary postmodern concept overcome it?"; 3 "Will the "classic arsenal' of identities persist in postmodern pluralist concept?" (It would be interesting to analyze whether the "current version" of the postmodern concept equally pluralistic as the original one).

2 On the issue of complex identity as identity composed of partial identities, see Lenovský (2005).

3 Thus, we move "from J.G. Frazer (et al.)" closer to Barbour (2000); Medawar (1998); Pannenberg (1993); or Shieman (2009).

4 For more on immigration and religious landscsape (on the example of Europe), see Valčo (2020).

5 For more information, see (e.g.,): Sedakova et al. (2019), or Žeňuch (2014).

6 There are numerous studies concerning the issue of historiography and ethnogenesis of Slovaks in the studied countries. For more on the "Low-land" Slovaks, see: Babiak (2001, pp. 107-32); Bartalská (2001b, pp. 87-100); Bartalská and Jančárová (2017); Kmet' (2010, 2013); Papuček and Balážová (2001, pp. 153-78); Štefanko (2001, pp. 233-52); for Slovaks in Argentina and Canada, see: Svetoň (1943, 1958); Bielik (1980); Kirschbaum (1967); Jakešová (1981, 1986, 1998); Jankovič (1996); Botík (2002); Čulen (1956); Stolarik (1978); Stolarik (2012), Kopanic (2007).

7 For example, the autobiography Stolarik (2012) on the issue of forming the identity of Slovak migrants.

8 On specific migration waves, currents, source and destination localities of Lower Earth Slovaks, more closely Sirácky, ed. (Sirácky 1980); Bielik, ed. (Bielik 1980); Bartalská, ed. (Bartalská 2001a) and Botík (Botík 2007).

9 On cultural heritage in axiological-aesthetic understanding, see: Babiak (2018).

10 On the socio-psychological approach to ethnic identity, see: Bačová (1990); and on the ethnocultural situation of Lowland colonists, see: Divičanová (2007).

11 "Intensive emigration movements from the territory of the current Slovak Republic were particularly evident from the second half of the nineteenth century until the First World War, when more than 500,000 persons left for the United States of America and another 350,000 for other regions of the world. Emigration continued both during the interwar period and under communism." (Divinský 2016, p. 291). On migration to Canada, see: Čulen (1956), Stolarik (1978); and to Argentina: Polakovič (1982, 1983), Jankovič (1996), Botík (2002). On the organization of emigration from Czechoslovakia, see: Tišliar (2014); Šmigel’ et al. (2015).

12 On the reasons for current emigration for work from the Slovak Republic, see Grenčiková et al. (2018).

13 On the ethnic mosaic, including religion, culture and ethnic diferencies in Balkan, see Akova and Kantar (2021).

14 There were no major population migrations in this city in the past one hundred years, which means that the Slovak majority has gradually assimilated and lost its Slovak ethnic identity.

15 For more on folk religiosity of Slovaks in Hungary, see: Žiláková (2011, 2016, 2018).

\section{References}

Akova, Sibel, and Gökmen Kantar. 2021. Globalization in the context of multiculturalism and ethnicity in the Western Balkans and intercultural communication. Journal of Public Affairs 21: e2185. [CrossRef]

Babiak, Michal. 2001. Juhoslávia. In Sprievodca slovenským zahraničím. Edited by L'ubica Bartalská. Bratislava: Dom zahraničných Slovákov, pp. 107-32.

Babiak, Michal. 2018. Kultúrne dedičstvo vojvodinských Slovákov v kontexte slovenskej kultúry. Museology and Cultural Heritage 6: 121-30.

Babiak, Michal. 2019. Tradícia bez Identity. Nadlak: Vydavatel'stvo Ivan Krasko.

Bačová, Viera. 1990. Etnická identita osobnosti-Sociálno-psychologický prístup. Slovenský Národopis 38: 508-14.

Barbour, G. Ian. 2000. When Science Meets Religion: Enemies, Stranger, or Partners? San Francisco: Harper.

Bartalská, L'ubica, ed. 2001a. Sprievodca Slovenským Zahraničím. Bratislava: Dom zahraničných Slovákov.

Bartalská, L'ubica. 2001b. Chorvátsko. In Sprievodca Slovenským Zahraničím. Edited by L'ubica Bartalská. Bratislava: Dom zahraničných Slovákov, pp. 87-100.

Bartalská, L'ubica, and Andrea Jančárová. 2017. Slováci v Chorvátsku. Available online: http://www.czsk.net/svet/clanky/svet/ slovacichorvat.html (accessed on 20 May 2021).

Bauman, Zigmund. 2001. Community: Seeking Safety in an Insecure World. Cambridge: Blackwell Publishing. 
Bielik, František, ed. 1980. Slováci vo Svete 2. Martin: Matica Slovenská.

Borgul'a, Michal, and Švihran Ladislav. 1979. Tu sa usadime: Slováci v čabianskej oblasti. Bratislava: Tatran.

Botík, Ján. 2002. Slováci v Argentínskom Chacu: Historický a etnokultúrny vývin pestovatel'ov bavlny. Bratislava: Lúč.

Botík, Ján. 2007. Etnická história Slovenska. Bratislava: Lúč.

Čulen, Konštantín. 1956. Slovaks in Slovakia and Canada. Winnipeg: Canadian Slovak League.

Deák, Ladislav. 1992. Poznámky k demografii Slovákov v Mad'arsku. SME, dvojčíslo časopisu. Budapešt' 14-15: 88. Available online: http:/ / www.oslovma.hu/index.php/sk/historia/166-historia3-historia3/573-ladislav-deak-poznamky-k-demografiislovakov-v-maarsku (accessed on 20 May 2021).

Divičanová, Anna. 2007. "Békéšski Slované", Pilíšania, Tirpáci. Varianty regionálnej a lokálnej identity. In Regionálna a národná identita v mad'arskej a slovenskej histórii 18-20. storočia. Edited by Štefan Šutaj and László Szarka. Prešov: Universum, pp. 104-10.

Divinský, Boris. 2016. Slovakia. In European Immigration: A Sourcebook. Edited by Anna Triandafyllidou and Ruby Gropas. London and New York: Routledge, pp. 291-305.

Eriksen, H. Thomas. 2002. Ethnicity and Nationalism. London: Pluto Press.

Filadelfi, Samuel. 2012. Slovenská menšina v krajinách bývalého Uhorska v období 1711-1918. Klaudyán: Internet Journal of Historical Geography and Environmental History 8-9: 26-42. Available online: http:/ /www.klaudyan.cz (accessed on 20 May 2021).

Grenčiková, Adriana, Ilona Skačkauskienè, and Jana Španková. 2018. The features of labor emigration from the Slovak republic. Business: Theory and Practice 19: 271-77. [CrossRef]

Jakešová, Elena. 1981. Vyst'ahovalectvo Slovákov do Kanady. Bratislava: VEDA.

Jakešová, Elena. 1986. Kanada. Bratislava: Obzor.

Jakešová, Elena. 1998. The impact of emigrants and reemigrants on Slovak society (1880's-1920's). Drustvena Istrazivanja 7: 27.

Jančovic, Ján. 2017. Tri storočia Slovákov v Békešskej Čabe. In Slovák v Mad'arsku. Available online: http:/ /www.oslovma.hu/index. $\mathrm{php/sk/historia/164-historia1-historia1/1348-tri-storoia-slovakov-v-bekeskej-abe} \mathrm{(accessed} \mathrm{on} 20$ May 2021).

Jankovič, Ladislav. 1996. Dva životy jeden osud. Bratislava: Dom zahraničných Slovákov.

Kirschbaum, M. Joseph. 1967. Slovaks in Canada. Toronto: Canadian Ethnic Press Association.

Kmet', Miroslav. 2010. Historiografia dolnozemských Slovákov v 19. storoči. Békešská Čaba: VÚSM.

Kmet', Miroslav. 2013. Historiografia dolnozemských Slovákov v prvej polovici 20. storočia. Kraków: Spolok Slovákov v Pol'sku.

Kokaisl, Petr, Andrea Štolfová, Jana Zychová, and Pavel Hanuš. 2014. Po stopách Slováků ve východní Evropě. Polsko, Ukrajina, Mad'arsko, Rumunsko, Srbsko, Chorvatsko a Černá Hora. Praha: Nostalgie.

Kopanic, J. Michael. 2007. Slovaks in America. In Studies in Ethnic Identity: Wandering Slovak People. Edited by Yoshimoto Kawasaki. Tokyo: Chuo University Press, pp. 209-41.

Kováčová, Anna. 2014. Po stopách slovenskej minulosti Budapešti. Budapešt'-Békešská Čaba: VÚSM.

Lenovský, Ladislav. 2005. Identity: (Today) a commodity among others (?). Filozofia 60: 536-41.

Lenovský, Ladislav. 2016. Naši vo svete—Slováci južne od hranice Slovenska I. Nadlak: KVSIK.

Lenovský, Ladislav. 2017. Naši vo svete—Slováci južne od hranice Slovenska II. Nadlak: KVSIK.

Lenovský, Ladislav. 2018. Naši vo svete—Slováci južne od hranice Slovenska III. Nadlak: KVSIK.

Medawar, Peter. 1998. The Limits of Science. Oxford: Oxford University Press.

Michela, Miroslav. 2009. Plans for Slovak autonomy in Hungarian politics 1918-1920 [Plány Slovenskej autonómie v politike Mad'arska 1918-1920]. Historický časopis 57: 271-97.

Pannenberg, Wolfhart. 1993. Toward a Theology of Nature. Essays on Science and Faith. Louisville: Westminster John Knox Press.

Papuček, Gregor, and Eva Balážová. 2001. Mad’arsko. In Sprievodca slovenským zahraničím. Edited by L'ubica Bartalská. Bratislava: Dom zahraničných Slovákov, pp. 153-78.

Paríková, Magdaléna. 2001. Ethnocultural and social contexts of postwar Slovak migration from Hungary. Human Affairs 11: 149-61. [PubMed]

Polakovič, Štefan. 1982. Čo je národné bytie? Hamilton: Slovenské vydavatel'stvo Františka J. Fugu.

Polakovič, Štefan. 1983. Vidiny o slovenskom národe. Buenos Aires: Zahraničná matica slovenská.

Šatava, Leoš. 1994. Národnostní menšiny v Evropě. Encyklopedická příručka. Praha: Ivo Železný.

Sedakova, Irina, Žeňuch Peter, and Kitanova Marija. 2019. Axiologický výskum slovanských jazykov/Axiological Investigation into the Slavic Languages. Bratislava and Moskva: Slavistický ústav Jána Stanislava SAV-Институт славяноведения PAH, VEDA.

Shieman, S. Bruce. 2009. Atheist Defends Religion: Why Humanity is Better Off with Religion Than Without. New York: Alpha Books.

Sirácky, Ján, ed. 1980. Slováci vo svete I. Martin: Matica Slovenská.

Šmigel', Michal, Pavol Tišliar, and Branislav Šprocha. 2015. Ethnic cleansings and a concept of ethnically homogenous states in Europe (in the context of historical experience and memory). In Resettlement and Extermination of the Populations: A Syndrome of Modern History. Edited by Zlatica Zudová-Lešková. Praha: Historický ústav, pp. 85-109.

Štefanko, Ondrej. 2001. Rumunsko. In Sprievodca slovenským zahraničím. Edited by L'ubica Bartalská. Bratislava: Dom zahraničných Slovákov, pp. 233-52.

Stolarik, Imrich. 1978. Spomienky Pionierov. Toronto: Kanadská slovenská liga.

Stolarik, M. Marian. 2012. Where is My Home? Slovak Immigration to North America. Bern: Peter Lang.

Svetoň, Ján. 1943. Slováci v európskom zahraničí. Turčiansky Svätý Martin: SAVU.

Svetoň, Ján. 1958. Obyvatel'stvo Slovenska za kapitalizmu. Bratislava: Vydavatel'stvo SVPL. 
Tišliar, Pavol. 2014. Beginnings of organisation of emigration in the Czechoslovak Republic. In Studies in the Population of Slovakia 2. Edited by Pavol Tišliar and Slavomír Čéplö. Kraków: Towarzystwo Słowaków w Polsce Zarząd Główny, pp. 43-62.

Valčo, Michal. 2020. Immigration and the future religious landscape of Europe. Theologos 22: 31-54.

Žeňuch, Peter. 2014. Kultúrne stereotypy v byzantsko-slovanskom konfesionálnom prostredí na Slovensku. Slavica Slovaca 49: 121-37.

Žiláková, Mária. 2011. Cirkevná kultúra mimo kánonu—ako špecifická vrstva tradičnej kultúry Slovákov v Mad'arsku. In Cirkevná kultúra Slovákov v Mad'arsku/A magyarországi szlovákok egyházi kultúrája. Otázky vývoja kultúry/A kultúrafejlődés kérdései II. Edited by Anna Divičanová and Anna Kováčová. Békešská Čaba: VÚSM, pp. 164-211.

Žiláková, Mária. 2016. Poslyšte mile, co chci spívati ... (Produkty jarmočnej tlacě-Zbierka pút'ových piesní ako rodinná relikvia)/Szeretettel hallgassátok, amit majd éneklek... (A cérnakö- nyv mint családi relikvia). (Opera Slavica Budapestinensia. Litteræ Slavicæ). Budapest: ELTE BTK Szláv Filológiai Tanszék.

Žiláková, Mária. 2018. L'udová religiozita Slovákov v Zadunajsku/A dunántúli szlovákok népi vallásossága. In Acta Ethnologica Danubiana 20. Az Etnológiai Központ Évkönyve. Edited by József Liszka. Komárom and Somorja: Fórum Kisebbségkutató Intézet Etnológiai Központ, pp. 141-45. 